\title{
Gamification Design for Waste Problems in Public Space (Case Study: Gajah Tunggal Park, Tangerang)
}

\author{
Nadia Mahatmi ${ }^{*}$, RR. Mega Iranti ${ }^{2}$ \\ ${ }^{1}$ Program Studi Desain Komunikasi Visual, Universitas Multimedia Nusantara, \\ Tangerang, Indonesia \\ ${ }^{2}$ Program Studi Film dan Televisi, Universitas Multimedia Nusantara, \\ Tangerang, Indonesia \\ *Penulis korespondensi; Email: nadia.mahatmi@umn.ac.id
}

\begin{abstract}
Waste is a problem that is always faced in every major city in Indonesia. Tangerang is one of the big cities in Indonesia that also faces problems with garbage. Even though every public space in Tangerang has provided trash bins, the level of community participation in disposing of garbage in its place is still low. To increase community participation, gamification can be used. However, before the gamification is designed, it has to first know the intrinsic motivation of people wanting to dispose of garbage in its proper place so that the gamification design is effective.
\end{abstract}

Keywords: Littering, Gamification, Intrinsic Motivation.

\begin{abstract}
Abstrak
Sampah merupakan masalah yang selalu dihadapi di setiap kota besar di Indonesia. Tangerang merupakan salah satu kota besar di Indonesia yang juga menghadapi masalah sampah. Meskipun setiap ruang publik di Tangerang telah menyediakan tempat sampah, namun tingkat partisipasi masyarakat dalam membuang sampah pada tempatnya masih rendah. Untuk meningkatkan partisipasi masyarakat dapat digunakan gamifikasi. Namun, sebelum gamification didesain, terlebih dahulu harus diketahui motivasi intrinsik orang yang ingin membuang sampah pada tempatnya agar desain gamification tersebut efektif.
\end{abstract}

Kata kunci: membuang sampah sembarangan, gamifikasi, motivasi intrinsik.

\section{Preliminary}

Waste is a big problem for Indonesia. According to data taken on February 5, 2018 at 14.16 from Janganbuangsampah.org, every day around $0.7 \mathrm{~kg}$ of waste are produced per person (Baqirah, 2019). In one year, the waste produced by the Indonesian population is around 5.4 million tons of waste. Of the many problems related to waste in Indonesia, Indonesian are still littering.

Based on observations made at Taman Gajah Tunggal (Gajah Tunggal Park) on October 26th, 2017, there is an interesting phenomenon regarding behaviour of disposing garbage in urban communities in Indonesia. Even though it has only been established for two months (from the opening of the park to the observation time), Taman Gajah Tunggal has the same garbage problems as other older public spaces in Indonesia: littering. As a result, the comfort and beauty of the park is reduced.
The reluctance of the community to dispose of garbage in its place is not due to the absence of facilities to garbage disposal, but also to the motivation of the community itself about the importance of environmental hygiene. Based on observations at Taman Gajah Tunggal, Tangerang City, Banten, there are already colorful trash cans stored at a short distance away from the center of activity and quite a large number. Another way is needed so that people want to dispose of garbage in its place, one of which is by gamification. This research will try to find out the intrinsic motivation of visitors about littering habit as the first of phase.

\section{Literary Study}

\section{Gamification}

Gamification is a process of incorporating game mechanics, game aesthetics, and game mindset to invite people to participate, motivate action, 
promote learning, and solve problems (Kapp, 2014 \& Deterding, et al., 2011). Gamification creates new models of participation, targets new communities of people, and motivates these people to achieve the final results that they themselves are not even aware of (Burke, 2015). The term 'gamification' was first used by Nick Pelling to describe his work as a consultant for making hardware more fun (Dale, 2014: 82-90).

Gamification can be done to increase civic engagement because basically humans are social creatures and their behavior is determined by the community where they are, both large and small (Hassa, 2017: 249-267). Meanwhile according to David Crowley of Social Capital, Inc., civic involvement is an active participation of a citizen in shaping a better life in their community (Adler \& Goggin, 2005: 236-253).

The use of game elements is considered as one of the things that can increase learning interest because there is a parallel relationship between playing games with learning outcomes (Jain \& Dutta, 2019: 29-44). Playing experience also relates to individual's self-esteem, satisfaction, emotions, motivation, catharsis, arousal, learning, competence, and various complex cognitive, phenomenal, and behavioral phenomena (Juul, 2013). There are various types of public services and other uses that can be enhanced through gamification (Asquer, 2014). In the past 40 to 50 years, decision makers have indicated that the use of board games, serious games, simulations, and role play has sufficient effects to be calculated in the context of civic outcomes (Eranpalo, 2014: 104-120).

In designing a gamification, Hamari mentioned three processes that must be done, namely motivational affordances, psychological outcomes, and the last is behavioral outcomes. It is important to know the main motivations before deciding to change citizen's habits (Hamari, et al., 2014: 3025-3034). Don't be trapped into making rhetorical gamification, which is an instant solution that only takes the surface view of a game without a deeper understanding of the user's psychological or design process (Landers, 2019: 137-140). Gartner said by 2014, $80 \%$ of gamification designs fail to meet their objectives because of poor design (Gordon, 2015).
According to Lobna Hassan, there are three stages that must be done in gamification design, namely motivational affordances, psychological outcomes, and behavioral outcomes (Hassa, 2017: 249-267). Good gamification design should be user-centric and not mechanism centric (Dale, 2014: 82-90).

\section{Intrinsic Motivation}

In the theory of motivation, there is something called a Sawyer Effect, which is a situation where people feel motivated to do something because they like it and not because of a reward or pressure. Lakhani and Wolf, as quoted by Pink states that intrinsic motivation based on enjoyment when doing something is the strongest and most persuasive drive (Pink, 2009). The same is true of what Frey said that "intrinsic motivation is the most important thing in all economic activities. It is unthinkable if people are motivated because of incentives from outside".

Intrinsic motivation can also be interpreted as non-survival needs, namely an ego motive such as curiosity, competence, autonomy, and play (Reiss, 2012: 152-156). Sometimes people use rewards in the hope that they can increase the motivation and habits of others, but unconsciously or intentionally damage the intrinsic motivation of the person to the activities carried out (Pink, 2009). Intrinsic motivation can be stated as an act of doing something because of inherent satisfaction, rather than having consequences (Ryan \& Deci, 2000: 5467).

There are three psychological needs that are at the core of intrinsic motivation. The first is the desire to learn new skills so as to reach perfection (mastery). The second is a feeling of free choice and the potential to behave in accordance with individual desires (autonomy) and the last is a feeling that someone is part of a community (relatedness) (Baard, et al., 2004: 2045-2068).

Martin et al. in his book entitled "The Small Big" states that human motivation basically consists of three large groups that are very strong, namely motivation to make decisions that are as accurate and efficient as possible, motivation to join and be accepted by others, and motivation to see themselves in a positive image (Martin, 2014). 
Yu-kai Chow, as reported in an article entitled "Octalysis - the Complete Gamification Framework", said that basically human motivation can be categorized into eight types, which he calls octalysis (Chou, 2014). Octalysis is an axis that still represents each of the basic human desires, which include:

1. Epic-meaning and calling

2. Development and accomplishment

3. Empowerment of creativity and feedback

4. Ownership and possession

5. Social influence and relatedness

6. Scarcity and impatience

7. Unpredictability and curiosity

8. Loss and avoidance

In motivation, there is also what is called public service motivation, namely one's orientation in delivering services to others with the aim of doing good to others and their environment (Hondeghem \& Perry, 2009: 5-9). It is important to know that there are different triggers for each personality (Dale, 2014: 8290).

\section{WHITE HAT MOTIVATION}

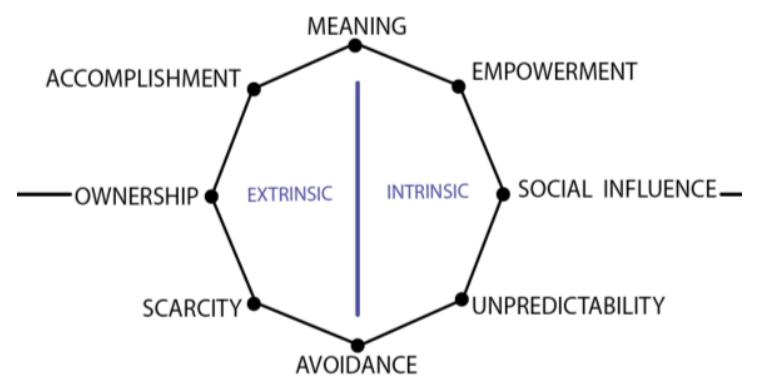

\section{BLACK HAT MOTIVATION}

Figure 1. Octalysis Diagram by Yukai Chow

\section{Methods}

The survey was conducted on 9-13 July 2018 to find data on the number of visitors to Taman Gajah Tunggal. The goal is to see visitor traffic and record the various types of visitors who come. This also would affect the main target of gamification made. The survey is divided into three sessions, namely 07.00-08.00, 12.0013.00, and 18.00-19.00. Visitors are then divided into age categories, namely children (012 years), adolescents (13-18 years), young adults (19-34 years), adults (35-55 years), and seniors ( $>55$ years).

There were 2378 visitors who came during the 5 days of observation. Of these 2378 people, the highest population is filled by the adult category (911 people) and the lowest population is filled by the elderly category (75 people). Thus the main target of this gamification design will be focused in adult.
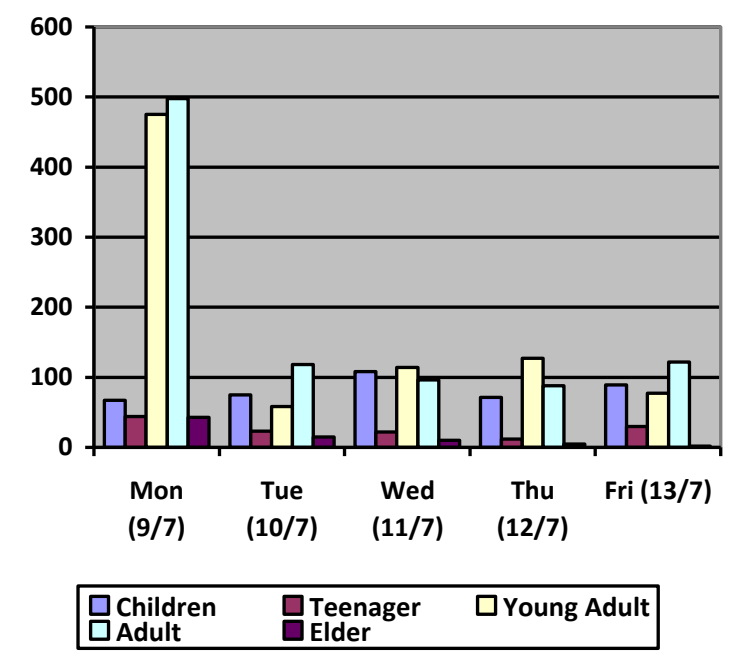

Figure 2. Numbers of visitors during 5 observation days

Forum Group Discussion (FGD) was conducted at Gajah Tunggal Park on Sunday, September 16,2018 at $08.00-16.00$ WIB. The purpose of this FGD is to know what kind of intrinsic motivation of visitors. The author selects visitors randomly, but still has social relations between each other. The FGD was conducted in three groups of visitors.

The FGD was carried out with 6 questions, namely the background of the participants, how many times had been to Gajah Tunggal Park, the usual activities carried out, the level of cleanliness at Gajah Tunggal Park, the habit of disposing of participant's trash, and things to be improved at Gajah Tunggal Park. All of these questions were asked to look for participants' views on cleanliness of Gajah Tunggal Park and their main motivation in maintaining environmental hygiene.

The first group consisted of five women, namely Rinny (51 years), Fitri Bela (20) from Toraja, Dena Melindasari (20 years) from Medan, Tirda Evilia (20 years) from Serang, and Novi Lustrianti (24 years) from Jakarta. Rinny is the boarding house owner of the other four women. This is the first time Fitri has been to Taman Gajah Tunggal.

The second FGD was conducted at four park visitors, namely Iwan Saputra (25 years) from East Lampung, Siti Fatimah (17 years) from 
East Lampung, Andri Setiawan (20 years) from Tangerang, and Yani Amani (20 years) from Tangerang. Iwan and Siti are coworkers at a convection company, while Andri and Yani are close friends from same hometown.

The third group of FGDs was Bella (15 years), Tari (15 years), Rian (19 years), and Alamin (18 years). Bella and Tari are high school students, while Rian and Alamin have graduated from high school and work as office boys in the same office. The four are native to Tangerang. Rian has visited the Gajah Tunggal Park 2-3 times and initiated his friends to visit this park as well.

Based on the results FGD conducted, the data was then analysed into the form of participants' empathy map. Of the 13 empathy maps that have been compiled there are some people whose personalities are similar so that finally empathy map is simplified into just five, namely Rinny, Iwan Saputra, Andri Setiawan, Jejen, and Alamin. Then each persona in empathy map was analysed again to be included in category 8 of basic human motivation. The results are as follows:

1. Rinny has the main motivation for empowerment, social influence, and avoidance. According to Rinny, the biggest achievement is when he can become a leader and role model for his surroundings. While one of the biggest fears is losing the opportunity that exists and is not seen as someone who has influence in their environment.

2. Iwan has the main motivation for social influence. For Iwan, who is a migrant, his greatest achievement is when he can influence people from his hometown to be as successful as he is. His biggest fear is if he is not seen as successful by people from his hometown.

3. Andri has the main motivations for accomplishment, social influence, and avoidance. For Andri, success is if he can be a human being that is useful for the nation and is able to be a good example for the environment. Meanwhile, his biggest fear is when he is unable to bring change to his environment.

4. Jejen has the main motivation for social influence and unpredictability. For Jejen, his biggest achievement was to make his family happy, while his biggest fear was not being able to fulfill the basic needs of his family.
5. Alamin has the main motivation for accomplishment, social influence, and unpredictability. According to Alamin, his biggest achievement is if he can be a role model on social media, while his biggest fear is if all the efforts that have been made do not have any impact on their existence, both in the real world and on social media.

\section{Conclusion}

The results of the previous analysis can be categorized as White Hat and Black Hat motivation. White Hat Motivation is an element of motivation that gives a feeling of being powerful, fulfilled, and satisfied, while Black Hat Motivation gives a feeling of being obsessed, anxious, and addicted. Ownership and social influence can be both White Hat and Black Hat Motivation based on the context.

\section{WHITE HAT MOTIVATION}

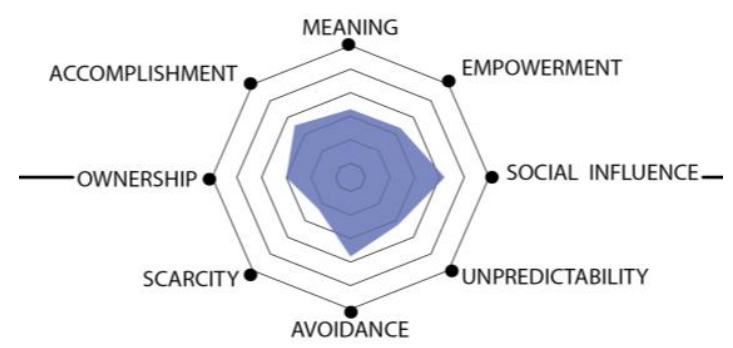

\section{BLACK HAT MOTIVATION}

Figure 3. The Result Shown in Octalysis Diagram

In this case, White Hat motivation is accomplishment and empowerment, while the Black Hat motivation is avoidance and unpredictability. In both accomplishment and empowerment, it can be seen that the main motivation of the majority is feeling to be useful and influencing the surrounding environment. While avoidance and unpredictability is an uneasy feeling considered not to be a role model for the surrounding environment even though it has done something.

But above all motivation shown in Figure 5, both Social Influence and Avoidance are ranked high enough. They can be drawn from the context of the habits and culture of Indonesian. Based on the value of country comparison conducted by Hofstede-Insights on its website, Indonesia has a collective value of 14 which means very collectively, while countries in North America, Europe and Australia are in the range of 90 which means very individualistic. 
It cannot be denied that social life has a huge influence on individuals in Indonesia. A person's self-confidence is closely related to group opinion, which can increase tension and uncertainty (Yaniv, et al., 2009: 558-563). Every individual is very dependent on their environment. Social grouping is divided into "you" and "us". Individuals who are in the social community depend on the group and are expected to be reciprocal in the form of loyalty.

Consideration of context is one of the most important things in designing successful gamification and needs to be emphasized that not all services are not suitable to be gamified (Hamari, 2013: 236-245). The relationship between game design and intrinsic interest and enjoyment cannot be used equally in all cases (Asquer, 2014). The final conclusion is that if gamification wants to be used to solve waste problems in Indonesia (case study: Taman Gajah Tunggal), intrinsic motivations of Social Influence and Avoidance should be fulfilled. Note that result in other cities might be different due to differences in culture, habits, etc.

\section{Acknowledgement}

Thank you to Friska Natalia Ferdinand, P.hD., RR. Mega Iranti, all Smart Park Team, Prof. Kunio Kondo and Prof. Koji Mikami from Tokyo University of Technology, and all the people whom I cannot mention one by one.

\section{References}

Adler, R. P. \& Goggin, J. 2005, What Do We Mean By "Civic Engagement"? Civic Ventures, Journal of Transformative Education Volume 3, No. 3, pp. 236-253.

Asquer, A. 2014, Not Just Videogames: Gamification and Its Potential Application to Public Services, In Digital public administration and E-government in developing nations: Policy and practice, Edited by E. F. Halpin. IGI Global.

Baard, P. P., Deci, E. L., \& Ryan, R. M. 2004, Intrinsic Need Satisfaction: A Motivational Basis Of Performance and Well-Being in Two Work Settings, V.H. Winston \& Son, Inc., Journal of Applied Social Psychology, Issue 34, pp. 2045-2068.

Baqirah, N. F. A. B. 2019, Timbunan Sampah Nasional Capai 64 Juta Ton per Tahun. https://ekonomi.bisnis.com/read/20190221/9 9/891611/timbulan-sampah-nasional-capai64-juta-ton-per-tahun.
Burke, B. 2015, Gamify: How Gamification Motivates People to Do Extraordinary Things, Routledge.

Chou, Yu-Kai. 2014, Actionable Gamification: Beyoind Points, Badges, and Leaderboards, Octalysis Media.

Dale, S. 2014, Gamification: Making work fun, or making fun of work? Sage Pub, Business Information Review Vol. 31(2), pp. 82-90.

Deterding, S., Dixon, D., Khaled, R., \& Nacke, L. 2011, From Game Design Elements to Gamefulness: Defining Gamification, Sagepub, In Proceedings of the 15th International Academic MindTrek Conference: Envisioning Future Media Environments, pp. 9-15.

Eränpalo, T. 2014, Exploring Young People's Civic Identities Through Gamification: A Case Study Of Finnish, Swedish and Norwegian Adolescents Playing A Social Simulation Game, Sage Pub, Citizenship, Social \& Economics Education, Issue 13, Vol.2, pp. 104-120.

Gordon, B. 2015. Will 80\% of Gamification Projects Fail? Giving Credit to Gartner's 2012 Gamification Forecast.

https://www.gameffective.com/will-80-ofgamification-projects-fail.

Hamari, J. 2013, Transforming Homo Economicus Into Homo Ludens: A Field Experiment on Gamification In A Utilitarian Peer-To-Peer Trading Service, Electronic Commerce Research and Applications, Issue 12, Vol.4, pp. 236-245.

Hamari, J., Koivisto, J., \& Sarsa, H. 2014, Does Gamification Work? A Literature Review Of Empirical Studies On Gamification. IEEE, In 2014 47th Hawaii International Conference on System Sciences (HICSS), pp. 3025-3034.

Hassa, L. 2017, Governments Should Play Games: Towards a Framework for the Gamification of Civic Engagement Platforms, Sage Pub, Simulation \& Gaming Vol. 48, No.2, pp. 249-267.

Hondeghem, A., \& Perry, J. L. 2009, EGPA Symposium On Public Service Motivation and Performance: Introduction, International Review of Administrative Sciences, Issue 75, pp. 5-9.

Jain, A \& Dutta, D. 2019, Millennials and Gamification: Guerilla Tactics for Making Learning Fun, Sage Pub, South Asian Journal of Human Resources Management, Volume 6(1), pp. 29-44.

Juul, J. 2013, The Art of Failure: An Essay on the Pain of Playing Video Games, The MIT Press. 
Kapp, Karl M, et al. 2014, The Gamification of Learning and Instruction Fieldbook: Ideas into Practice, Wiley.

Landers, R. 2019, How Badly Executed and Rhetorical Gamification Obscures Its Transformative Potential, Sage Pub, Journal of Management Inquiry, Volume 28, pp. 137-140.

Martin, Steve J., et al. 2014, The Small Big: Small Changes that Spark Big Influence, Grand Central Publishing.

Pink, D H. 2009, Drive: The Surprising Truth about What Motivates Us, Riverhead Books.

Reiss, S. 2012, Intrinsic and Extrinsic Motivation, Sage Pub, Teaching of Psychology, Volume 39, Issue 2, pp. 152156.
Ryan, R., \& Deci, E. 2000, Intrinsic and Extrinsic Motivations: Classic Definitions and New Directions, Sage Pub, Contemporary Educational Psychology, Volume 25, pp. 54-67.

Yaniv, I., Choshen-Hillel, S., \& Milyavsky, M., 2009, Spurious Consensus and Opinion Revision: Why Might People Be More Confident In Their Less Accurate Judgments? Sage Pub, Journal of Experimental Psychology: Learning, Memory, and Cognition, Volume 35, pp. 558-563. 